\title{
The deleterious effects of human erythropoietin gene driven by the rabbit whey acidic protein gene promoter in transgenic rabbits
}

\author{
M Massoud 1, J Attal 2, D Thépot 2, H Pointu 2, MG Stinnakre 3, \\ MC Théron 2, C Lopez ${ }^{4}$, LM Houdebine ${ }^{2 *}$ \\ 1 Unité d'endocrinologie de l'embryon; \\ 2 Unité de différenciation cellulaire; \\ 3 Laboratoire de génétique biochimique, Inra, 78352 Jouy-en-Josas cedex; \\ 4 Institut national de la transfusion sanguine, 6, rue Alexandre-Cabanel, 75015 Paris, France
}

(Received 25 April 1996; accepted 26 July 1996)

\begin{abstract}
Summary - Human erythropoietin (EPO) gene and CDNA associated with the rabbit whey acidic protein (WAP) gene promoter were used to tentatively produce the recombinant protein in milk of transgenic mice and rabbits. Several gene constructs showed good efficiency in the mouse mammary cell line $\mathrm{HC} 11$. None of them was able to direct the expression of the hormone at a concentration higher than $50 \mu \mathrm{g} / \mathrm{mL}$ in mouse and rabbit milk. With one of the construct, the rabbits had an abnormally high amount of red blood cells irrespectively of their sex, they could not reproduce and no milk could be obtained from them. These animals died prematurely. In these animals, the EPO gene was therefore expressed at a low but supraphysiological level in organs other than the mammary gland. These experiments show that transgenic animals obtained with gene constructs which do not contain insulators cannot be used as living fermentors to produce human erythropoietin in their milk at an industrial scale.
\end{abstract}

human erythropoietin / transgenic rabbits and mice / milk

Résumé - Effet néfaste du gène de l'érythropoïétine humaine placé sous le contrôle du promoteur du gène de la whey acidic protein de lapin chez des lapins transgéniques. Le gène et l'ADNc de l'érythropoḯtine (EPO) humaine associés au promoteur du gène de la protéine acide du lactosérum (WAP) de lapin ont été utilisés pour essayer de produire la protéine recombinante dans le lait de souris et de lapins transgéniques. Plusieurs constructions de gène se sont exprimées à un haut niveau dans la lignée mammaire de souris HC11. Aucune de ces constructions n'a été capable de permettre une sécrétion de l'hormone à une concentration supérieure à $50 \mu \mathrm{g} / \mathrm{mL}$ dans le lait de souris et de lapin.

\footnotetext{
${ }^{*}$ Correspondence and reprints
} 
Avec une de ces constructions les lapins avaient une quantité anormalement élevée de globules rouges indépendamment de leur sexe, ils n'ont pu se reproduire et aucun échantillon de lait n'a pu être obtenu. Ces animaux de plus sont morts prématurément. Chez ces animaux, le gène de l'érythropoiétine s'est de toute évidence exprimé à un taux faible mais supraphysiologique dans des tissus autres que la glande mammaire. Ces expériences montrent que les animaux transgéniques obtenus avec ces constructions de gène qui ne contiennent pas d'isolateurs ne peuvent pas être utilisés comme fermenteurs vivants pour préparer des quantités d'érythropoïetine humaine à une échelle industrielle.

\section{érythropö̈étine / souris et lapin transgéniques / lait}

\section{INTRODUCTION}

Erythropoietin (EPO) is a hormone which plays a major role in red blood cell formation. It is produced by a minor population of renal cells (Da Silva et al, 1994) and by the liver. The clinical use of this hormone, which is potentially high, is still limited by its availability. Only a very small quantity of the hormone can be obtained from human kidneys. Its production as a recombinant protein can be performed but animal cells must be used for this purpose. The hormone is $\mathrm{N}$ and $\mathrm{O}$ glycosylated and bacteria cannot generate the molecule in its fully functional state (Jelkmann, 1992; Delorme et al, 1992). Human EPO is produced by different animal cell lines (Takeuchi et al, 1989; Yanagi et al, 1989; Delorme et al, 1992; Nimtz et al, 1993; Lopez et al, 1994) and by yeast (Elliot et al, 1989). The recombinant hormone produced by animal cells in culture is biologically active although not glycosylated as the native molecule (Davis et al, 1987).

The milk from transgenic animals has been demonstrated to be a valuable source of functional recombinant proteins (see review Houdebine, 1994, 1995). The regulatory regions from different milk protein genes are used for this purpose. Among these DNA sequences, the upstream region of the rabbit whey acidic protein (WAP) gene has been shown to direct the expression of foreign genes with high efficiency (Devinoy et al, 1994).
Mice are commonly used to evaluate the efficiency of gene constructs to be used in larger animals. Rabbits are considered as a possible species to produce recombinant proteins in sufficient quantity for pharmaceutical use (Houdebine, 1994).

In the present work, the cDNA and the gene coding for the human EPO have been fused io the rabbit WAP gene promoter. Four constructs were used. They were tested in the mouse mammary cell line $\mathrm{HC11}$. One and three of them were used to generate transgenic mice and rabbits, respectively.

\section{MATERIALS AND METHODS}

\section{Gene constructs}

The plasmid $p 1$ contained the rabbit WAP gene promoter $(6.3 \mathrm{~Kb})$ used in our previous study (Devinoy et al, 1994) and the complete human EPO gene with its own transcription terminator (Pugh et al, 1991; Lopez et al, 1994). The plasmid p2 was similar to the p1 but the EPO gene transcription terminator was replaced by the rabbit WAP gene fragment $(3.9 \mathrm{~Kb})$ containing the transcription terminator. The plasmid $\mathrm{p} 3$ contained the rabbit WAP gene promoter, a 5'UTR, which stimulates translation. This element was used in a previous study (Petitclerc et al, 1995) and will be described elsewhere: the EPO CDNA (Lopez et al, 1994), the SV40 late gene intron, VP1, and the SV40 late gene terminator. These two latter elements are present in the vector pSVL (Amersham, Les Ulis, France). All these elements were bordered by two matrix attached regions (MAR). 
In the 5'P end, the MAR located in the 3 'OH human end of the apolipoprotein B100 gene (Levy-Wilson and Fortier, 1989) was added before the WAP gene promoter. In the $3^{\prime} \mathrm{OH}$ end, two copies of the SV40 MAR (Pommier et al, 1990) were added after the SV 40 terminator. The plasmid p4 contained the rabbit WAP gene promoter followed by the entire human growth hormone (hGH) gene. The hEPO cDNA associated to the 5'UTR described earlier was introduced in the last exon of the hGH gene, at the Aspl site. This sequence allows a reinitiation of mRNA translation (unpublished data).

All these plasmids were in pPolylll (Lathe et al, 1987) and are shown in figure 1. The inserts for microinjection were released from the plasmids after digestion with Not I.

\section{Cell transfection}

The mouse mammary cell line $\mathrm{HC} 11$ was transfected by lipofectin as recommended by the manufacturer. In all cases cells were transfected 1 day after trypsinization. Two plasmids were cotransfected: the plasmids containing the EPO gene $(8 \mu \mathrm{g})$ and the plasmid pRSVneor for clone selection $(2 \mu \mathrm{g})$ for each $60 \mathrm{~mm}$ diameter dish. Each transfection was carried out in two dishes. The mixted clones were amplified, cultured in $10 \%$ fetal calf serum containing $10 \mathrm{ng} / \mathrm{mL}$ EGF and insulin $(5 \mu \mathrm{g} / \mathrm{mL})$ until hyperconfluency. Induction was performed by adding insulin $(5 \mu \mathrm{g} / \mathrm{mL})$, dexamethasone $\left(10^{-6} \mathrm{M}\right)$ and prolactin $(5 \mu \mathrm{g} / \mathrm{mL})$ in the medium without EGF as described by Ball et al (1988). After 2 days, the media were collected and EPO concentration was estimated using a commercial kit (Lopez et al, 1994).

\section{Generation of transgenic mice and rabbits}

Transgenic mice were obtained by injecting 1-2pl of linear inserts corresponding to about 500 copies of the genes. Transgenic rabbits were obtained in the same way, following the protocol described in our previous work (Massoud et al, 1991; Dunn et al, 1995).

Transgenes were identified by PCR from ear DNA extracted by Gene-Clean as previously described (Attal et al, 1995).

Milk was collected under vacuum after injections of oxytocin to lactating females. EPO concentration in milk and blood was evaluated using the commercial kit used for culture media.

Data reported here were those directly obtained using the kit, without subtracting the values found in serum and milk from control animals.

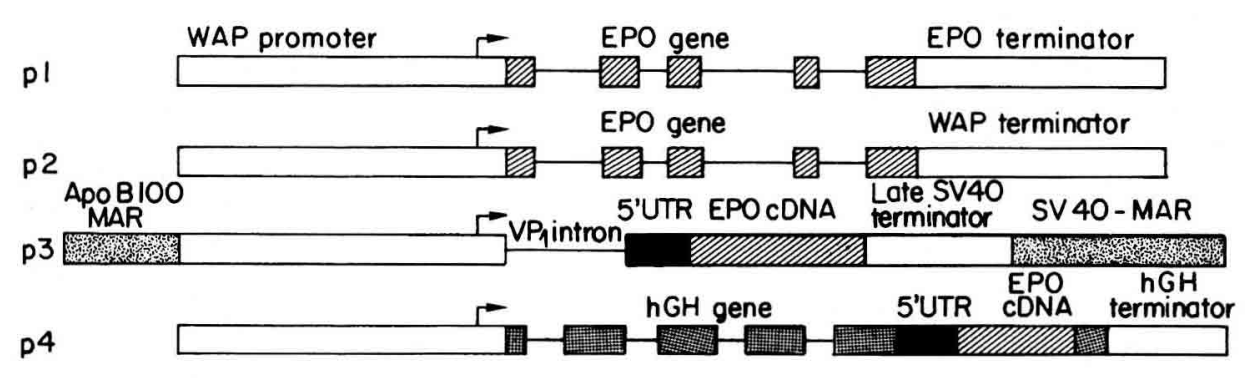

Fig 1. Schematic representation of the gene constructs containing the hEPO cDNA and gene. WAP is the $6.3 \mathrm{~Kb}$ upstream fragment of the rabbit WAP gene; 5 UTR is a sequence previously used (Petitclerc et al, 1995); hGH is the complete human growth hormone gene; VP1 is the SV40 late gene intron; the transcription terminators are from rabbit WAP gene, from hEPO gene, from hGH gene or from SV40 late genes; MAR are the matrix attached region from human apolipoprotein B100 and from SV40 (two copies of the SV40 MAR are present in the plasmid p3). Drawings are not on scale for the different DNA fragments. 


\section{RESULTS}

\section{Expression of the constructs of HC11 cells}

To evaluate the efficiency of the gene constructs, stable clones of the mouse mammary cell lines HC11 harboring hEPO constructs were obtained and induced by lactogenic hormones.

The results shown in figure 2 indicate that the plasmid $p 1$ was poorly efficient. Previous works carried out by several laboratories have shown that a DNA region sensitive to oxygen concentrations is located in the $3^{\prime} \mathrm{OH}$ flanking sequence of the EPO gene (Semenza et al, 1991; Blanchard et al, 1992; Semenza and Wang, 1992; Maxwell et al, 1993). This sequence may contribute to reduce expression of the plasmid $\mathrm{p} 1$ in $\mathrm{HC} 11$ cells. The terminator from rabbit WAP gene was much more potent than the EPO terminator (fig 2). The plasmid p2 was therefore retained to generate transgenic animals.

The plasmids $\mathrm{p} 3$ and $\mathrm{p} 4$ were also transfected into $\mathrm{HC} 11$ cells. Up to $500 \mathrm{ng} / \mathrm{mL}$ of EPO was secreted in the culture medium of stable clones under lactogenic hormone stimulation (not shown).

In the absence of dexamethasone, a background secretion of hEPO was observed. This is probably due to glucocorticoids present in calf serum. In these experimental conditions, the background may be reduced by maintaining the cells in the absence of serum for at least 2 days. Prolactin showed only very limited stimulatory effect. For unknown reasons, the same thing was observed in the $\mathrm{HC} 11$ cells transfected with different gene constructs containing the rabbit WAP and $\alpha \mathrm{S} 1$-casein promoter fused to various reporter genes although the endogenous $\beta$-casein gene showed high dependency towards prolactin to be induced (not shown). The experiment reported in figure 2 is therefore indicative of the potency of the gene constructs but they do not reflect a clear hormonal action.

\section{The expression of the hEPO gene in transgenic mice}

The insert of the plasmid p2 was used to generate transgenic mice. Twelve founder animals were obtained. The concentration of hEPO in their blood was measured when

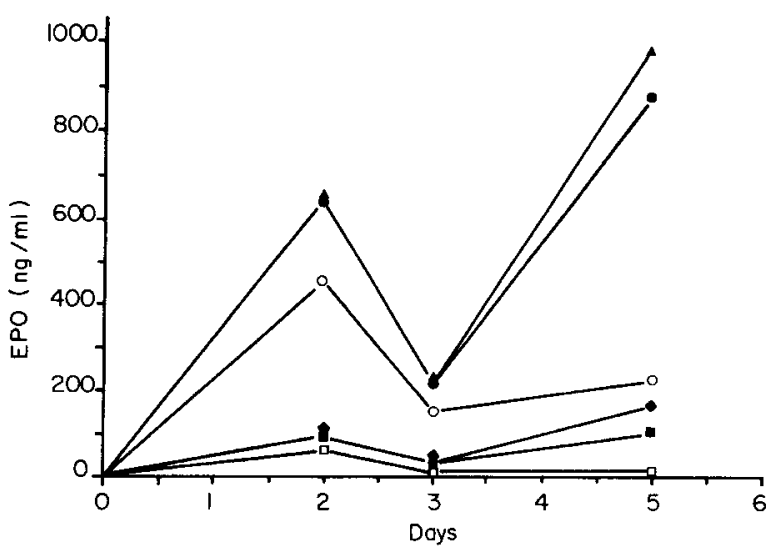

Fig 2. Expression of hEPO gene constructs in $\mathrm{HC} 11$ cells. Stable clones at hyperconfluency were induced by dexamethasone and prolactin for 2 days. Insulin was present throughout the culture. hEPO was measured in the culture medium. Results are the means of duplicates from two dishes transfected independently. Plasmid $p 1$ (with EPO gene terminator): $\square$ control; $\mathbf{\square}+$ dexamethasone; + dexamethasone + prolactin. Plasmid p2 (with WAP gene terminator) : $O$ control; $*+$ dexamethasone; $\Delta+$ dexamethasone + prolactin. 
Table I. Concentration of hEPO in serum and milk from transgenic mice harboring the insert from plasmid p2.

\begin{tabular}{lcc} 
Mouse & $\begin{array}{c}E P O \text { in serum } \\
(n g / m L)\end{array}$ & $\begin{array}{c}E P O \text { in milk } \\
(n g / m L)\end{array}$ \\
\hline 33 & 2.4 & 950 \\
34 & 34 & 750 \\
49 & 0.5 & ND \\
67 & 0 & ND \\
68 & 0 & ND \\
72 & 0 & 2 \\
78 & 18 & ND \\
81 & 9 & ND \\
85 & 0 & 50000 \\
88 & 59 & 3750 \\
92 & 0.4 & 830 \\
110 & 0.4 & 10000 \\
Control & 9 & 0 \\
\hline
\end{tabular}

Serum samples were collected in adult founders. Milk samples were collected from founders and from $F 1$ females when founders were males. Some of the founders were not reproduced and no milk samples were obtained from them (ND). they were adults. In a control animal, the equivalent of $9 \mathrm{ng} / \mathrm{mL}$ of hEPO was found. Values lower than $9 \mathrm{ng} / \mathrm{mL}$ are therefore not significant. This reflects an interference of the mouse serum with the hEPO ELISA test. Only three mice showed, therefore, a significant but limited amount of hEPO in their blood (table I). The presence of hEPO in blood of the transgenic mice did not appear to be related to the sex of the animals. The hEPO in blood results most likely, therefore, from an ectopic expression of the transgene and not from a transfer of the hormone from the mammary gland to blood circulation. The same phenomenon was observed in transgenic mice harboring the hGH gene driven by the rabbit WAP gene promoter (Devinoy et al, 1994).

Some of the mice were reproduced to obtain milk samples. When males were founders milk was obtained from $\mathrm{F} 1$ females. Significant but quite variable amounts of hEPO were found in milk from most of the transgenic mice and not in a control animal. None of these animals showed particular health problems.

Table H. Concentration of hEPO in serum and milk from transgenic rabbits harboring the inserts from plasmids p2, p3 and p4.

\begin{tabular}{|c|c|c|}
\hline & Gene construct & $\begin{array}{c}\text { EPO in serum } \\
(n g / m L)\end{array}$ \\
\hline
\end{tabular}

\begin{tabular}{lccc}
\hline 13 & & ND & ND \\
33 & $\mathrm{p} 2$ & 140 & 800 \\
51 & & 0 & ND \\
11 & $\mathrm{p} 3$ & 0.05 & 50000 \\
18 & & 0 & ND \\
8 & & ND & \\
14 & $\mathrm{p} 4$ & ND & ND \\
10 & & ND & ND
\end{tabular}

The serum samples were from adult founders. Milk samples were obtained from founder females. The animals in which measurements were not carried out are noted ND. 


\section{The expression of hEPO gene in transgenic rabbits}

The gene construct p2 was also used to generate transgenic rabbits. Three founders were obtained. The male 13 died before any blood sampling was performed and before giving offspring. hEPO was found in blood of the female 33 but not of the female 51 (table II).

In the milk of female $33,800 \mathrm{ng} / \mathrm{mL}$ of hEPO was found (table II). This animal was apparently healthy. It gave birth to one transgenic female which died before becoming an adult.

The female 51 became pregnant twice but aborted each time. This animal was abnormally lean. To obtain offspring it was superovulated and sacrified. Only 13 embryos were obtained. They were transferred to a recipient female. Seven animals were born and one male was transgenic. This animal died prematurely.

Two founder transgenic rabbits were also obtained with the gene construct p3. Both had only a negligible amount of hEPO in their blood (table II). The male 18 died prematurely and gave no offspring. The female 11 gave birth to seven rabbits and among them, three were transgenic. The milk from the female 11 contained $50 \mu \mathrm{g} / \mathrm{mL}$ of hEPO. This animal and its offspring were apparently healthy.

To tentatively obtain higher concentrations of hEPO in milk, the gene construct p4 was injected into the rabbit embryos. Three transgenics were obtained (table II). The male 10 died prematurely and no samples were obtained from it. The female 14 and the male 8 showed a slower growth and hardly reached the normal size of an adult rabbit. The female 14 was mated repeatedly. It became pregnant several times but aborted in all cases at mid-pregnancy. No milk could therefore be obtained from this animal which was obviously not healthy and died after a year and a half. The male 8 was subfertile. However, offspring was obtained from it. One rabbit was transgenic and died prematurely. Another did not live long enough to be studied. The male 8 died after $11 / 2$ years.

Rabbits 8 and 14 were obviously not healthy. Collecting blood from the ear vein of these animals proved to be difficult. Blood was abnormally viscous and extremely rich in red blood cells. Only a small quantity of serum was obtained and did not allow a precise estimation of hEPO concentration.

\section{DISCUSSION}

The experiments depicted here show with no ambiguity that $h E P O$ can be obtained in milk from transgenic animals. The possibility to use transgenic animals as an alternative to cultured cells to produce hEPO has been examined by several groups. Transgenic rabbits secreting very low levels of $\mathrm{hEPO}$ in their milk have been obtained (Castro et al, 1994). A transgenic calf has also been generated (Hyttinen et al, 1994). The efficiency of the transgene is still unknown.

In the present work, several gene constructs expressing hEPO gene were used. The construct $\mathrm{p} 2$ was only moderately efficient in mice and rabbit. This is in clear contrast with the $\mathrm{HC} 11$ cells which expressed this construct at a high level. Transgenes are known to be much better expressed when their transcribed region was native genes with their introns rather then cDNA (Palmiter et al, 1991; Petitclerc et al, 1995). Unexpectedly, the hEPO gene, even devoid of its $3^{\prime} \mathrm{OH}$ flanking sequence, was poorly efficient. The introns may contain silencers which reduce the expression of the hEPO gene in non-renal and -liver cells.

The construct $\mathrm{p} 3$ was perhaps more potent but still quite insufficient to envisage a commercial utilization of the transgenic rabbits. 
The stability of the hEPO in mouse and rabbit milk was not evaluated. Although unlikely, such an instability might explain why the hEPO did not accumulate in the milk transgenic animals.

With the construct $p 4$, the health of the transgenic rabbits were obviously severely impaired. This is clearly due to an ectopic expression of the transgene. Previous work showed that the WAP promoter present in transgenes is active preferentially but not strictly in the mammary gland (Devinoy et al, 1994). The presence of hEPO in blood in males as in females resulted in exceeding red blood cell numbers, a fact already observed in transgenic mice harboring the native EPO gene (Semenza et al, 1989, $1990,1991)$. EPO produced by different tissues of the transgenic rabbits obviously altered several biological functions of the animals.

In some cases, the ectopic expression of transgenes can be strongly reduced by the presence of insulators added on both sides of the constructs. In these conditions as well, all the animals express the transgenic in a copy-dependent manner. The number of identified insulators is small and their mechanism of action is still poorly understood (Sippel et al, 1996). Such an approach has been retained by Hyttinen et al (1994). The beneficial effect of the MAR added in this construct is not yet known. In construct $\mathrm{p} 3$, the MAR may have contributed to reduce hEPO secreting in blood. This is by no means certain, however, since the same vector with reporter genes did not drive the expression of these genes only in the mammary gland and as a function of an integrated copy number (Attal et al, 1996). Insulating transgenes will probably be possible in the future. The possibility to switch off and on a transgene by inducers or repressors such as tetracycline also offers an interesting perspective in this respect (Furth et al, 1994). With such vectors, the transgenes can be spontaneously expressed and switched off by tetracycline or the reverse. Another problem still remains, however. The transfer of whey proteins such as $\alpha$-lactalbumin or WAP from milk to blood is a natural process (Grabowski et al, 1991). The recombinant proteins present in milk are also transferred to blood during lactation, irrespectively of an ectopic expression of the transgene. This was clearly observed in mouse transgenic lines expressing human $\alpha-1$ antitrypsin (Bischoff et al, 1993), hGH (Devinoy et al, 1994) and bGH (Thépot et al, 1995) in their milk. Hence, it may be expected that even animals in which the hEPO transgene is conveniently insulated will suffer from excess of the hormone transferred from milk to blood as soon as their lactation starts. This will be particularly crucial in the rabbit in which milk synthesis starts 2 weeks before parturition (Puissant et al, 1994).

A possible alternative consists of producing a biologically inactive precursor of hEPO followed by an in vitro biochemical activation; however, this is probably a difficult task.

Another possibility might be to use an animal species in which the hEPO is only weakly active. It is not certain, however, that transgenesis can be performed easily in such a species.

The present work suggests that transgenic animals are probably not good candidates to produce recombinant hEPO in their milk. Interestingly, the direct transfer of the hEPO gene to somatic cells by adenoviral vectors offers attractive new possibilities (Tripathy et al, 1994).

\section{REFERENCES}

Attal J, Cajero-Juarez M, Houdebine LM (1995) A simple method of DNA extraction from whole tissues and blood using glass powder for detection of transgenic animals by PCR. Trans Res 4, 149-150

Attal $J$, Cajero-Juarez $M$, Petitclerc $D$, Théron MC, Stinnakre MG, Bearzotti M, Kann G, Houdebine LM 
(1996) The effect of matrix attached regions (MAR) and specialized chomatin structure (SCS) on the expression of gene constructs in cultured cells and in transgenic mice. Mol Biol Rep 22, 37-46

Ball RK, Früs RR, Schoenenberger CA, Doppler N, Groner B (1988) Prolactin regulation of $\beta$ casein gene expression of a cytosolic $120 \mathrm{kd}$ protein in a cloned mouse mammary epithelial cell line. EMBO J 7, 2089-2095

Bischoff R, Degryse E, Perraud F, Dalemans W, AliHadji D, Thépot D, Devinoy E, Houdebine LM, Pavirani A (1992) A $17.6 \mathrm{kbp}$ region located upstream of the rabbit WAP gene directs high level expression of a functional human protein variant in transgenic mouse milk. FEBS Lett 305, 265-268

Blanchard KL, Acquaviva AM, Galson DL, Bunn HF (1992) Hypoxic induction of the human erythropoietin gene: cooperation between the promoter and enhancer, each of which contains steroid receptor response elements. Mol Cell Biol 12, 5373-5385

Castro FO, Aguirre A, Fuentes P, Ramos B, Rodriguez $A$, De La Fuente J (1995) Secretion of human erythropoietin by mammary gland explants from lactating transgenic rabbits. Theriogenology 43, 184

Da Silva JL, Schwartzmann ML, Goodman A, Levere RD, Abraham NG (1994) Localization of erythropoietin mRNA in the rat kidney by polymerase chain reaction. J Cell Biochem 54, 239-246

Davis JM, Arakawa T, Strickland TW, Yphantis DA (1987) Characterization of recombinant human erythropoietin produced in Chinese hamster ovary cells. Biochemistry 26, 2633-2638

Delorme E, Lorenzini T, Giffin J, Martin F, Jacobsen F, Boone T, Elliott $S$ (1992) Role of glycosylation on the secretion and biological activity of erythropoietin. Biochemistry 31, 9871-9876

Devinoy $E$, Thépot $D$, Stinnakre $M G$, Fontaine $M L$, Grabowski H, Puissant C, Pavirani A, Houdebine LM (1994) High level production of human growth hormone in the milk of transgenic mice: the upstream region of the rabbit whey acidic protein (WAP) gene targets transgene expression of the mammary gland. Trans Res 3, 79-89

Dunn CS, Mehtali M, Houdebine LM, Gut JP, Kirn A, Aubertin AM (1995) Human immunodeficiency virus type 1 infection of human CD4-transgenic rabbits. J Gen Virol 76, 1327-1336

Elliott S, Giffin J, Suggs S, Lau EP, Banks AR (1989) Secretion of glycosylated human erythropoietin from yeast directed by the $\alpha$-factor leader region. Gene 79 , 167-180

Furth PA, St Onge L, Böger H, Gruss P, Gossen M, Kistner A, Bujard $H$, Hennighausen $L$ (1994) Temporal control of gene expression in transgenic mice by a tetracycline-responsive promoter. Proc Natl Acad SciUSA 91, 9302-9306

Grabowski H, Le Bars D, Chene N, Attal J, MalienouN'Gassa R, Puissant C, Houdebine LM (1991) Rab- bit whey acidic protein concentration in milk, serum, mammary gland extract and culture medium. J Dairy Sci $74,4143-4150$

Houdebine LM (1994) Production of pharmaceutical proteins from transgenic animals. J Biotech 34,269 287

Houdebine LM (1995) The production of pharmaceutical proteins from the milk of transgenic animals. Reprod Nutr Dev 35, 609-617

Hyttinen JM, Peura T, Tolvanen M, Aalto J, Alhonen L, Sinervirta R, Halmekytö M, Myöhänen S, Jänne J (1994) Generation of transgenic dairy cattle from transgene-analyzed and sexed embryos produced in vitro. Biotechnology 12, 606-608

Jelkmann W (1992) Erythropoietin: structure, control of production and function. Physiol Rev 72, 449-489

Lathe R, Vilotte JL, Clark AJ (1987) Plasmid and bacteriophage vectors for excision of intact inserts. Gene 57, 193-201

Levy-Wilson B, Fortier C (1989) The limits of the DNase I-sensitive domain of the human apolipoprotein B gene coincide with the locations of chromosomal anchorage loops and define the 5 ' and 3 ' boundaries of the gene. J Biol Chem 264, 21196-21204

Lopez C, De Chesnay A, Tournamille C, Ben Ghanem A, Prigent S, Drouet X, Lambin P, Cartron JP (1994) Efficient production of biologically active human recombinant proteins in human lymphoblastoid cells from integrative and episomal expression vectors. Gene 148, 285-291

Massoud M, Bishoff R, Dalemans W, Pointu H, Attal J, Schultz H, Clesse D, Stinnakre MG, Pavirani A, Houdebine LM (1991) Expression of active recombinant human alpha1-antitrypsin in transgenic rabbits. J Biotech 18, 193-204

Maxwell PH, Pugh CW, Ratcliffe PJ (1993) Inducible operation of the erytropoietin 3 ' enhancer in multiple cell lines: evidence for a widespread oxygen-sensing mechanism. Proc Natl Acad Sci USA 90, 2423-2427

Nimtz M, Martin W, Wray V, Kloppel KD, Augustin J, Conradt HS (1993) Structures of sialylated oligosaccharides of human erythropoietin expressed in recombinant BHK-21 cell. Eur J Biochem 213, 39-56

Palmiter D, Sandgren EP, Avarbock MR, Allen DD, Brinster RL (1991) Heterologous introns can enhance expression of transgenes in mice. Proc Natl Acad Sci USA 88, 478-482

Petitclerc D, Attal J, Théron MC, Bearzotti M, Bolifraud $P$, Kann G, Stinnakre MG, Pointu $H$, Puissant $C$, Houdebine LM (1995) The effect of various introns and transcription terminators on the efficiency of expression vectors in various cultured cell lines and in the mammary gland of transgenic mice. J Biotech 40, 169-178

Pommier Y, Cockerill PN, Kohn KW, Garrard WT (1990) Identification within the simian virus 40 genome of a 
chromosomal loop attachment site that contains topoisomerase II cleavage sites. J Virol 64, 419-423

Pugh CW, Tan CC, Jones RW, Ratcliffe PJ (1991) Functional analysis of an oxygen-regulated trancriptional enhancer lying 3 ' to the mouse erythropoietin gene. Proc Natl Acad Sci USA 88, 10553-10557

Puissant C, Bayal-Sarmadi M, Devinoy E, Houdebine LM (1994) Variation of transferrin mRNA concentration in the rabbit mammary gland during the pregnancy-lactation-weaning cycle and in cultured mammary cells. A comparison with the other major milk protein mRNAs. Eur J Endocrinol 130, 522-529

Semenza GL, Wang GL (1992) A nuclear factor induced by hypoxia via de novo protein synthesis binds to the human erythropoietin gene enhancer at a site required for transcriptional activation. Mol Cell Biol 12 , 5447-5454

Semenza GL, Traystman MD, Gearhart JD, Antonarakis SE (1989) Polycythemia in transgenic mice expressing the human erythropoietin gene. Proc Natl Acad Sci USA 86, 2301-2305

Semenza GL, Traystman MD, Gearhart JD, Antonarakis SE (1990) Human erythropoietin gene expression in transgenic mice: multiple transcription initiation sites and cis-acting regulatory elements. $\mathrm{Mol} \mathrm{Cell}$ Biol 10, 930-938

Semenza GL, Koury ST, Nejfelt MK, Gearhart JD, Antonarakis SE (1991) Cell-type-specific and hypoxia-inducible expression of the human erythropoietin gene in transgenic mice. Proc Natl Acad Sci USA 88, 8725-8729

Sippel AE, Saueressig $H$, Huber MC, Faust N, Bonifer (1996) Insulation of transgenes from chromosomal position effects. In: Transgenic Animals. Generation and Use (LM Houdebine, ed), Harwood Academic Publisher, Amsterdam, the Netherlands

Takeuchi M, Inoue N, Strickland TW, Kubota M, Wada M, Shimizu R, Hoshi S, Kozutsumi H, Takasaki S, Kobata A (1989) Relationship between sugar chain structure and biological activity of recombinant human erythropoietin produced in Chinese hamster ovary cells. Proc Natl Acad Sci USA 86, 7819-7822

Thépot $D$, Devinoy $E$, Fontaine ML, Stinnakre MG, Massoud M, Kann G, Houdebine LM (1995) Rabbit whey acidic protein gene upstream region controls highlevel expression of bovine growth hormone in the mammary gland of transgenic mice. Mol Reprod Dev $42,261-267$

Tripathy SK, Goldwasser E, Lu M, Barr E, Leiden JM (1994) Stable delivery of physiologic levels of recombinant erythropoietin to the systemic circulation by intramuscular injection of replication-defective adenovirus. Proc Natl Acad Sci USA 91, 11557-11561

Yanagi H, Yoshima T, Ogawa I, Okamoto M (1989) Recombinant human erythropoietin produced by namalwa cells. DNA 8, 419-427 